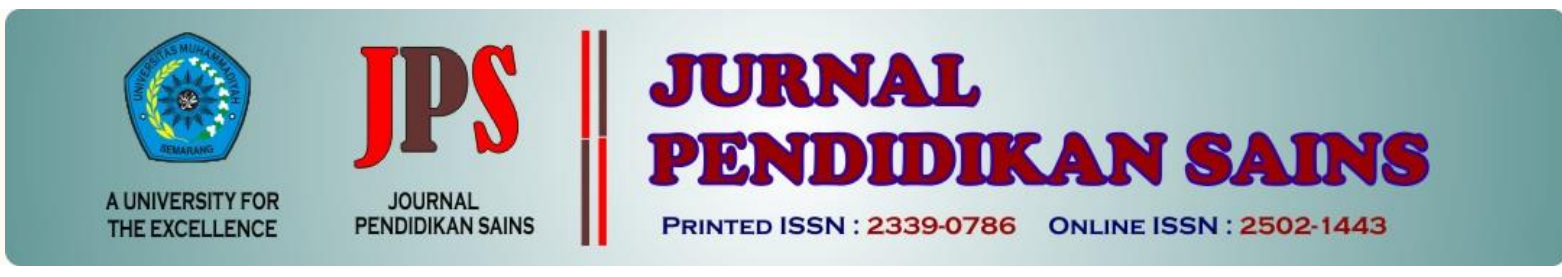

http://jurnal.unimus.ac.id/index.php/JPKIMIA

\title{
PENGARUH PENGGUNAAN MEDIA PEMBELAJARAN MACROMEDIA FLASH CS 6 TERHADAP HASIL BELAJAR KOGNITIF SISWA PADA MATERI SISTEM PEREDARAN DARAH MANUSIA
}

Oleh:

Zusette Ruslinda Wamiau*, Lusiawati Dewi, Santoso Sastrodihardjo

Program Studi Pendidikan Biologi, Fakultas Biologi, Universitas Kristen Satya Wacana Salatiga

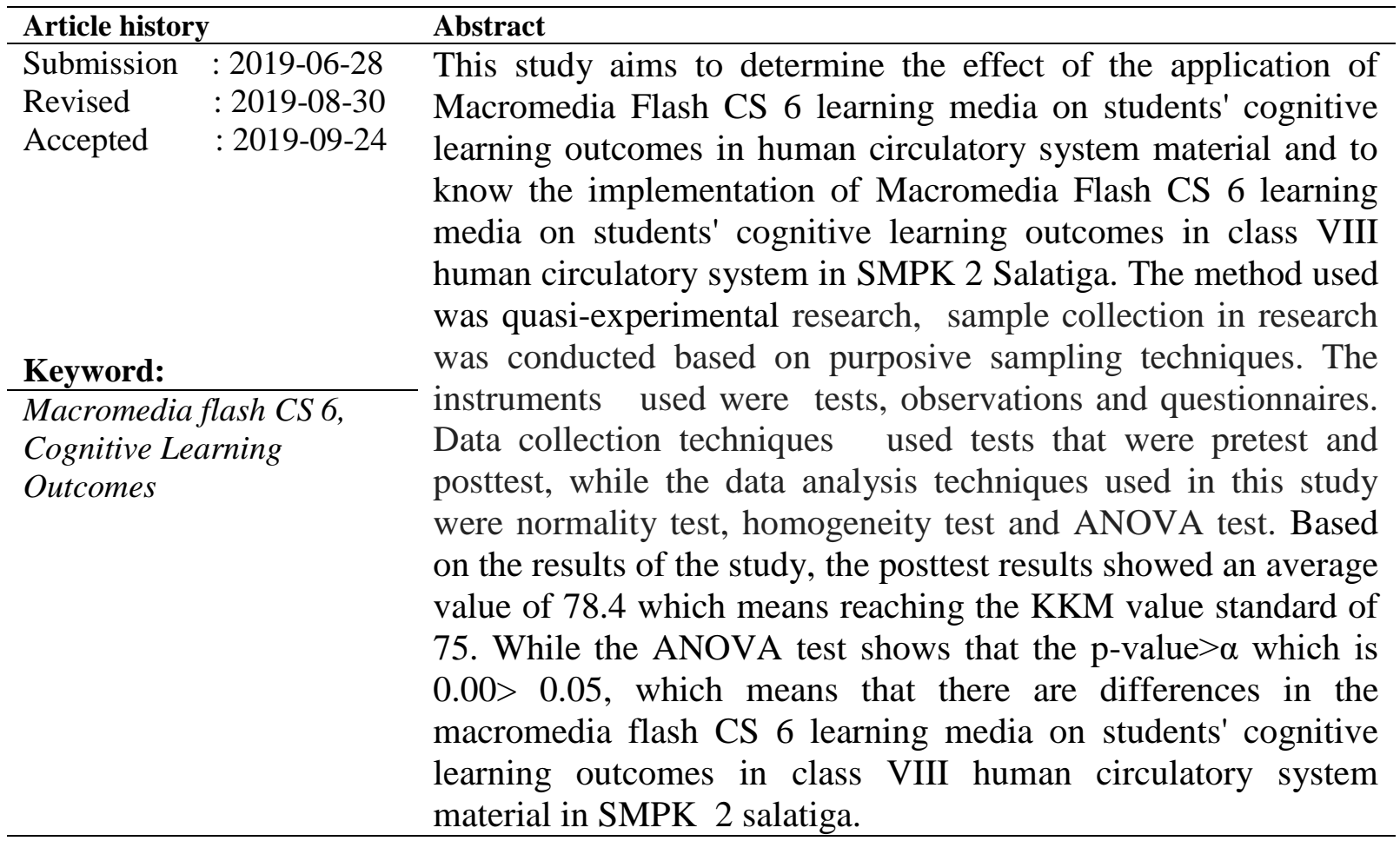

\section{Pendahuluan}

Kurikulum pendidikan di Indonesia mengalami perubahan dari Kurikulum Tingkat Satuan Pendidikan (KTSP) menjadi Kurikulum 2013 yang merupakan salah satu upaya penyempurnaan pendidikan. Perubahan kurikulum tidak terlepas dari upaya untuk melibatkan peran siswa dalam proses pembelajaran melalui pendekatan saintifik. Proses belajar yang berorientasi pada siswa menjadi peluang agar kemampuan siswa dapat diberdayakan secara holistik. Pengembangan kompetensi siswa secara menyeluruh bertujuan untuk untuk membentuk sumber daya manusia yang potensial bagi kemajuan bangsa. 
$\begin{array}{ccc}\text { Kemajuan } & \text { suatu } & \text { bangsa } \\ \text { membutuhkan peran serta } & \text { seluruh }\end{array}$ komponen pendidikan khususnya guru sebagai ujung tombak pelaksana kurikulum. Pelaksanaan kurikulum oleh guru dapat diterapkan melalui model pembelajaran. Model pembelajaran merupakan salah satu prosedur yang di gunakan secara sistemati untuk mencapai tujuan pembelajaran melalui strategi, tekni, metode, bahan pembalajaran dan alat pembelajaran. Namun seringkali muncul permasalahan terhadap penyampaian pesan yang kurang optimal karena terjadinya kesalahan penyampaian antara guru dan siswa (Affandi, et al., 2013). Proses komunikasi yang berlangsung di kelas pada umumnya dilakukan secara lisan atau tulisan tanpa disertai perangkat pendukung lainnya dengan tujuan untuk lebih memperjelas materi yang disampaikan oleh guru (Palupi \& Anitah, 2014). Proses belajar mengajar pada hakikatnya merupakan proses komunikasi melalui suatu media tertentu yang di dasarkan oleh kurikulum yang berlaku.

Media merupakan alat komunikasi baik secara audivisual maupun secara visual. Menurut (Santyasa, 2007) bahwa tanpa penggunaan media sebagai alat komunikasi maka proses komunikasi dalam pembelajaran tidak akan optimal. Seiring dengan adanya perkembangan teknologi, terdapat banyak strategi penggunaan teknologi dalam pembelajaran yang dapat dimanfaatkan salah satuya adalah macromedia flash. Strageti dengan pembelajaran berbasis teknologi informasi dapat berlangsung tanpa dibatasi oleh ruang dan waktu (Nasirudin \& Mawartiningsih, 2017) sehingga dapat meningkatkan keaktifan siswa. Penggunaan teknologi informasi melalui pemanfaatan macromedia flash diharapkan dapat memberikan kontribusi yang nyata terhadap perubahan proses pembelajaran yang berlangsung di sekolah. Artinya kegiatan pembelajaran yang dilakukan tidak lagi berpusat pada proses mendengarkan penjelasan materi dari guru yang terkesan bersifat monoton dan cenderung membosankan (Muhson,2010). Komunikasi dalam lembaga sekolah sangat penting guna memperlancar interaksi antara guru,siswa dan lingkungan sekolah dengan memberikan informasi secara cepat dan tepat agar proses pembelajaran dapat berjalan dengan baik.

Kondisi siswa pada tingkat sekolah menengah pertama sebagian besar tergolong dalam kelompok remaja yang pada kenyataannya mampu bersikap adaptif dalam merespon perkembangan teknologi dan informasi. Berdasarkan data yang diperoleh Kemkominfo tahun 2014 bahwa pengguna komputer dan internet di Indonesia mencapai 82 juta dan $80 \%$ penggunanya adalah remaja. Dalam mata pelajaran IPA siswa tidak sematamata diajarkan untuk memahami konsep IPA akan tetapi siswa diharapkan mampu menumbuhkan sikap ilmiah. Selain itu, siswa diharapkan dapat berperan aktif dalam menjaga kelestarian lingkungan alam sekitar. Akan tetapi, tujuan tersebut tidak akan tercapai oleh siswa ketika guru kurang mampu menyampaikan materi ajar dengan baik (Setyono, Eka, \& Deswita, 2017). Sehingga siswa memiliki sedikit kesempatan untuk terlibat secara aktif serta sulit dalam mengembangkan ketrampilan sosial dan interpersonal siswa.

Salah satu upaya yang dapat dilakukan dalam melibatkan siswa secara aktif yaitu dengan penggunaan media pembelajaran. Macromedia flash adalah software yang membuat sajian visual berupa media seperti video, animasi, gambar dan suara untuk menarik minat peserta didik dalam memahami materi yang diajarkan (Gustina, Nur Abu, \& Hamsyah, 2016). Penyajian dalam macromedia flash memberikan kemudahan bagi siswa untuk memahami karena dapat disampaikan bahkan digunakan sendiri oleh siswa melalui proses visualisasi serta animasi sehingga tampilan gambar menjadi lebih hidup. Penyajian materi pelajaran yang menarik dan mudah untuk dipahami merupakan salah satu strategi yang digunakan untuk menarik rasa ingin tahu siswa untuk memahami tiap materi 
pelajaran yang disampaikan (Hilda, Yetri, \& Putra, 2018). Perkembangan teknologi pendidikan yang berkembang saat ini dapat mendukung pembuatan media pembelajaran yang berkualitas sehingga mampu memberikan pemahaman siswa terhadap konsep-konsep yang diajarkan serta mampu meningkatkan minat dan hasil belajar siswa.

Beberapa penelitian sebelumnya yang dilakukan menunjukkan adanya pengaruh yang signifikan terhadap hasil belajar kognitif melalui penggunaan media pembelajaran macromedia flash, diantaranya adalah penelitian yang dilakukan oleh (Citrasukmawati, Rahardjo, \& Tjandrakirana, 2012) dalam penelitiannya menunjukkan bahwa perangkat pembelajaran IPA dengan tampilan macromedia flash efektif dalam meningkatkan hasil belajar siswa. Selain itu (Cahyadi, 2014) yang dalam penelitiannya menyatakan bahwa media pembelajaran IPA berbasis macromedia flash mampu meningkatkan hasil belajar siswa. Pada penelitian yang dilakukan diharapkan penerapan macromedia flash CS 6 mampu meningkatkan hasil belajar siswa pada materi sistem peredaran darah manusia.

Kehadiran multimedia bisa menjadi salah satu alternatif media pembelajaran yang murah, atraktif, dan inovatif. Meski memang tak bisa dipungkiri bahwa ada hal-hal substansi dalam pembelajaran yang tidak bisa digantikan dengan media pembelajaran. Harapannya hasil belajar kognitif siswa dapat meningkat jika dilakukan melalui penggunaan macromedia flash secara langsung (Nurharyani, Sardimi, \& Jumrodah, 2015). Materi dalam penelitian ini adalah sistem peredaran darah manusia yang dikemas dalam penyajian materi mengenai struktur dan fungsi organ peredaran darah manusia, animasi mekanisme peredaran darah manusia, serta struktur dan fungsi pembuluh darah. Hal ini dilakukan untuk memberikan proses berpikir siswa secara komprehensif mengenai kaitan antara teori dan aplikasi dalam kehidupan sehari-hari. Tujuan dari penelitian ini adalah untuk mengetahui pengaruh penerapan media pembelajaran macromedia flash CS 6 terhadap hasil belajar kognitif siswa pada materi sistem peredaran darah manusia kelas VIII SMP Kristen 2 Salatiga dan mengetahui pelaksanaan media pembelajaran macromedia flash CS 6 terhadap hasil belajar kognitif siswa pada materi sistem peredaran darah manusia.

\section{Metode Penelitian}

Jenis Penelitian

Penelitian ini dalam pelaksanaanya menggunakan pendekatan kuantitatif. Penelitian ini termasuk dalam jenis penelitian quasi eksperimen design atau eksperimen semu dengan model one group pretest posttest. Penelitian eksperimen semu merupakan penelitian yang berbentuk hubungan sebab akibat melalui adanya perlakuan dan menguji perubahan akibat perlakuan tersebut (Sugiyono, 2010).

Penelitian ini dilakukan di SMP Kristen 2 Salatiga, yang beralamat di Jl.Jendral Sudirman No. 111B, Kec.Tingkir, Kota Salatiga, Jawa Tengah. Penelitian dilaksanakan pada semester genap Tahun Ajaran 2018/2019.

Pengambilan sampel pada penelitian ini berdasarkan teknik purposive sampling. Peneliti memilih menggunakan teknik ini karena peneliti menentukkan sendiri sampel yang diambil berdasarkan pertimbangan tertentu.

Subjek pada penelitian ini yaitu siswa kelas VIII A SMP Kristen 2 Salatiga semester genap tahun ajaran 2018/2019 dengan jumlah 26 siswa yang terdiri dari 12 laki-laki dan 14 perempuan.

Prosedur Penelitian

Penelitian ini menggunakan desain one group pretest posttest. Penelitian ini melibatkan satu kelas sebagai kelompok tunggal. Peneliti menggunakan design penelitian ini karena dirasa cocok dengan judul penelitian yang diambil, sebelum diberi treatment kelompok tunggal diberi test yaitu pretest untuk mengetahui pemahaman awal siswa terhadap materi sistem peredaran darah manusia. Setelah Kemudian setelah diberikan treatment kelompok tunggal diberi test yaitu posttest untuk mengetahui sejauh mana 
pemahaman siswa terhadap materi sistem peredaran darah manusia (Arikunto Suharsini, 2010).

\section{Instrumen dan Teknik Pengumpulan Data}

Data dalam penelitian ini dikumpulkan dengan menggunakan tes, lembar observasi dan angket kuesioner. Pada penelitian ini digunakan pendekatan kuantitatif. Adapun data yang diolah adalah data tes tertulis yaitu data hasil pretest dan data hasil posttest. Instrumen yang digunakan adalah tes. Tes dilakukan dengan memberikan bentuk soal pilhan ganda yang berhubungan dengan materi sistem peredaran darah manusia sebagai hasil belajar kognitif dengan mencakup $\mathrm{C} 1$ dan $\mathrm{C} 2$ siswa. Dalam pembuatan soal didasarkan pada kisi-kisi pembelajaran kognitif yang di dapat pada kompetensi dasar.

\section{Teknik Analisis Data}

Data yang diperoleh dalam penelitian ini terdiri dari data hasil tes awal (pretest) dan data hasil tes akhir (posttest). Data tersebut kemudian dianalisis secara statistik deskripti dan Inferensial. Analisis statistik inferensial dimaksudkan untuk menguji hipotesis penelitian, untuk menguji hipotesis penelitian terlebih dahulu dilakukan uji prasyarat data. Pengolahan data statistik dilakukan dengan bantuan SPSS 16.0. Adapun analisis data yang dilakukan diawali dengan uji normalitas data, kemudian dilanjutkan dengan uji homogenitas, dan diakhiri dengan uji anova.

Uji Normalitas

Uji normalitas digunakan untuk mengetahui apakah sampel yang digunakan pada penelitian ini berasal dari populasi yang berdistribusi normal atau tidak. Uji normalitas ini menggunakan One-sample KolmogorovSmirnov pada SPSS. Data dikatakan berdistribusi normal jika pada output Kolmogorov- Smirnov nilai koefisien Asymptotic Sig > dari nilai alpha yang ditentukan, yaitu $5 \%(0,05)$. Sebaliknya jika nilai koefisien Asymptotic Sig $<0,05$ maka data dinyatakan tidak berdistribusi normal (Oktaviani, et al., 2014).

\section{Uji Homogenitas}

Uji homogenitas digunakan untuk mengetahui apakah sampel yang digunakan pada penelitian ini memiliki variansi yang sama (homogen) atau tidak. Uji homogenitas ini menggunakan Uji Levene pada SPSS 16.0.
Data dikatakan homogen jika pada output $U j i$ Levene > nilai tabel, atau harga koefisien $\mathrm{Sig}>$ dari nilai alpha yang ditentukan, yaitu 5\% $(0,05)$. Sebaliknya jika Uji Levene < nilai tabel, atau harga koefisien Sig < 0,05 maka data dinyatakan tidak homogen (Hartati, et al., 2013).

\section{Uji Hipotesis}

Uji hipotesis yang dilakukan pada penelitian ini menggunakan uji anova, dengan ketentuan sebagai berikut: a) taraf signifikansi ( $\alpha)=0,05$ atau $5 \%$; b) kriteria yang digunakan dalam Uji-t adalah $\mathrm{H}_{\mathrm{o}}$ diterima apabila Sig > 0,05 .

\section{Hasil Penelitian dan Pembahasan}

Hasil penelitian yang diperoleh melalui implementasi penggunaan macromedia flash melalui hasil belajar kognitif menggunakan instrumen pilihan ganda. Data berupa skor hasil tes yang diberikan kepada siswa selanjutnya diubah menjadi nilai. Berikut tabel 1 hasil belajar kognitif melalui sebaran statistik pretest dan posttest kemampuan kogniitf siswa pada kelas yang diberikan perlakuan media macromedia flash.

Tabel 1. Data Nilai Pretest Siswa

\begin{tabular}{ll}
\hline Deskripsi Hasil Belajar Kognitif & Hasil \\
\hline Nilai rata-rata & 48,0 \\
Nilai maksimal & 90 \\
Nilai minimal & 30 \\
Standar deviasi & 19,39 \\
Persentase ketuntasan belajar & $3,84 \%$ \\
Persentase ketidaktuntasan belajar & $96,1 \%$ \\
\hline
\end{tabular}

Berdasarkan hasil penelitian pada Tabel 1 dapat dilihat bahwa rata-rata pretest kemampuan kognitif siswa yaitu 48,0 sementara standar deviasi menunjukkan nilai yang cukup tinggi yaitu 19,39. Hal ini menunjukkan bahwa terdapat jarak yang cukup jauh antara nilai maksimal dengan nilai minimal dari kemampuan awal siswa. Setelah pembelajaran yang menggunakan macromedia flash selesai dilaksanakan maka diberikan kembali tes hasil belajar kognitif (posttest). Hal ini dilakukan agar dapat mengetahui pengaruh pembelajaran yang menggunakan macromedia terhadap hasil belajar kognitif. Bentuk tes yang diberikan diakhir pembelajaran sama dengan tes yang diberikan pada saat sebelum pembelajaran. 
Berdasarkan Tabel 2 rata-rata nilai posttest lebih besar dibandingakn nilai pretest. Hal ini menunjukkan bahwa terdapat peningkatan kemampuan kognitif siswa ditinjau dari selisih kenaikan pretest dan posttest.

\section{Tabel 2. Hasil Belajar Kognitif Posttest}

Proses pelaksanaan pembelajaran menggunakan macromedia flash dilaksanakan oleh peneliti dengan melakukan validasi media terlebih dahulu. Hasil yang diperoleh terhadap validasi media berdasarkan penilaian ahli media telah memenuhi kriteria penilaian media dan dinyatakan layak untuk digunakan yaitu 3,50 (valid). Data pretets dan posttest yang diperoleh melalui pelaksanaan macromedia flash digunakan untuk mengetahui adanya pengaruh penggunaan macromedia flash terhadap hasil belajar. Analisis data dilakukan dengan menggunakan uji prasyarat dan uji hipotesis.

Uji prasyarat yang digunakan adalah uji normalitas dan homogenitas. Uji normalitas digunakan untuk mengetahui distribusi data secara normal sementara uji homogenitas digunakan untuk mengetahui perbedaan keragaman dalam satu kelompok. Berdasarkan hasil uji normalitas dengan kriteria Komogorov-Smirnov diperoleh hasil Sig. = 0,906 . Hal ini menunjukkan bahwa nilai $\mathrm{Sig}>\alpha$ yaitu $0,906>0,05$. Hal ini menunjukkan bahwa $\mathrm{H}_{\mathrm{o}}$ ditolak yang artinya data pretest berdistribusi normal. Data posttest berdasarkan uji nilai Kolmogorov-Smirnov menunjukkan nilai sig.= 0,962 dengan ketentuan $0,962>0,05 \mathrm{H}_{\mathrm{o}}$ ditolak artinya data posttest berdistribusi normal. Berikut penyajian data pad Tabel 3. Mengeni uji normalitas menurut Kolmogorov -Smirnov:

Tabel 3. Uji Normalitas menurut kriteria uji Kolmogorov-Smirnov

\begin{tabular}{lcc}
\hline Perlakuan & Sig. & Keputusan \\
\hline Pretest & 0,906 & Berdistribusi normal \\
Posttest & 0,962 & Berdistribusi normal \\
\hline
\end{tabular}

Data yang telah berdistribusi normal selanjutnya dapat diuji dengan uji homogenitas. Uji homogenitas data pretest dan posttest diuji menggunakan kriteria Levene-test. Perolehan homogenitas data disajikan pada tabel 4 .
Tabel 4. Uji Homogenitas menurut kriteria uji

\begin{tabular}{lcc}
\multicolumn{3}{c}{ Levene-test } \\
\hline Levene statistic & Sig. & Keputusan \\
\hline 1,060 & 0,416 & Homogen \\
\hline
\end{tabular}

Berdasarkan pada tabel 4 uji homogenitas menggunakan kriteria Levene test

\begin{tabular}{ll}
\hline Deskripsi Hasil Belajar Kognitif & Hasil \\
\hline Nilai rata-rata & 78,4 \\
Nilai maksimal & 100 \\
Nilai minimal & 40 \\
Standar deviasi & 17,59 \\
Persentase ketuntasan belajar & $65,38 \%$ \\
Persentase ketidaktuntasan belajar & $34,61 \%$ \\
\hline
\end{tabular}
diperoleh hasil Sig. $=0,416$ yang menunjukkan bahwa 0,416>0,05 sehingga Ho ditolak. Hal ini menujukkan bahwa data pretest dan posttest bersifat homogen. Berdasarkan hasil uji prasyarat menunjukkan bahwa data bersifat normal dan homogen, maka pengujian hipotesis menggunakan uji Anova dapat dilakukan. Hasil perhitungan uji Anova dapat dilihat pada Tabel 5.

Tabel 5. Uji Anova

\begin{tabular}{cccc}
\hline $\begin{array}{c}\text { Mean } \\
\text { Square }\end{array}$ & F & $\begin{array}{l}\text { Sig (2- } \\
\text { tailed })\end{array}$ & Kesimpulan \\
\hline 535,417 & 7,692 & 0,00 & $\begin{array}{c}\text { Adanya } \\
\text { perbedaan }\end{array}$ \\
\hline
\end{tabular}

Berdasarkan Tabel 5 uji Anova diperoleh hasil sig. $=0,00$ yang menunjukkan bahwa Sig. 2 tailed $<\alpha$ yaitu $0,00<0,05$. Jika sig. 2 tailed $<\alpha$ artinya Ho ditolak sehingga terdapat perbedaan pada penggunaan macromedia flash CS 6 terhadap hasil belajar kognitif siswa pada materi sistem peredaran darah manusia kelas VIII SMP Kristen 2 Salatiga.

Berdasarkan perolehan data pretest nilai rata-rata siswa adalah 48,0 sedangkan nilai rata-rata posttest 78,4 . Dari data yang diperoleh terdapat adanya peningkatan sebelum dan sesudah diberikan perlakuan, salah satu faktor yang mendorong peningkatan hasil belajar siswa yaitu perhatian siswa terhadap media pembelajaran yang menggunakan macromedia flash pada materi sistem peredaran darah manusia (Situmorang \& Andayani, 2019). Pada pelaksanaan penelitian, terlebih dahulu siswa diberikan pretest dengan tujuan mengetahui pemahaman awal siswa terhadap materi sistem peredaran darah manusia sebelum menggunakan media pembelajaran macromedia flash. Kemudian dilanjutkan dengan kegiatan 
proses pembelajaran menggunakan media pembelajaran berupa macromedia flash.

Pada saat pembelajaran berlangsung terlihat kebanyakan siswa merasa antusias dalam mengikuti proses pembelajaran. Pada akhir pembelajaran siswa diberikan posttest dengan tujuan untuk mengetahui pencapaian hasil belajar kognitif terhadap materi sistem peredaran darah manusia. Berdasarkan uji Anova menunjukkan bahwa Ho ditolak sehingga terdapat pengaruh penggunaan macromedia flash terhadap hasil belajar kognitif siswa pada materi sistem peredaran darah manusia kelas VIII SMP Kristen 2 Salatiga (Tabel 5).

Selama pembelajaran berlangsung siswa melakukan berbagai aktivitas visual, auditori (mendengar) dan menganalisis. Aktivitas visual (visual activities) diantaranya aktivitas membaca, memperhatikan gambar demostrasi, percobaan dan pekerjaan orang lain sedangkan aktivitas analisis dapat dieksresikan dalam berbicara (oral activities) antara lain menyatakan, merumuskan, bertanya, memberi saran, mengeluarkan pendapat, mengadakan wawancara,diskusi dan interupsi (Sardiman, 2011). Tantangan guru dalam mengajarkan materi sistem peredaran darah adalah karena materi tersebut bersifat abstrak dan membutuhkan pengamatan langsung serta konkrit bagi siswa (Seh, Situmorang, \& Hastuti, 2018).

Peneliti memilih menggunakan macromedia flash agar pembelajaran menjadi lebih menarik. Hal ini terbukti dari pelaksanaan proses pembelajaran yang dapat meningkatkan hasil belajar siswa dari pretest ke posttest. Selain itu, macromedia juga dapat menarik perhatian siswa dalam mengikuti proses pembelajaran yang diberikan oleh guru sehingga siswa menjadi lebih aktif. Pada penelitian ini ditemukan siswa antusias dalam kegiatan mengamati serta mengumpulkan berbagi informasi yang disajikan dalam macromedia flash. Hal ini dikarenakan, macromedia flash yang digunakan juga menyediakan lembar aktivitas siswa sehingga siswa dapat melakukan aktivitas serta demostrasi berdasarkan informasi yang mereka peroleh dari macromedia flash. Jadi, selain melihat gambar, video serta aktivitas auditori siswa juga dapat mengolah informasi tersebut dalam aktivitas siswa dalam kelompok. Proses ini sekaligus membuktikan bahwa macromedia flash memberikan peran dan manfaat yang cukup besar bagi siswa dalam proses belajarnya (Nurchaili, 2010).

Meningkatnya hasil belajar siswa yang diperoleh pada hasil posttest menujukkan bahwa implementasi penggunaan media pembelajaran macromedia flash CS 6 terhadap hasil belajar kognitif siswa pada materi sistem peredaran darah manusia pada saat pembelajaran dikatakan telah memenuhi nilai KKM 75.

\section{Kesimpulan dan Saran}

Simpulan

Berdasarkan hasil penelitian dan pembahasan maka dapat disimpulkan bahwa penggunaan media pembelajaran macromedia flash CS 6 berpengaruh signifikan terhadap peningkatan hasil belajar kognitif siswa pada materi sistem peredaran darah manusia. Pada uji anova menujukkan bahwa nilai sig.2 tailed $=0,00$ hal ini menyatakan bahwa nilai sig. 2 tailed $<\alpha$ yaitu $0,00<0,05$ sehingga dapat disimpulkan bahwa penerapan media pembelajaran macromedia flash CS 6 berpengaruh terhadap peningkatan hasil belajar kognitif siswa.

Penggunaan media pembelajaran dengan menggunakan macromedia flash CS 6 pada hasil belajar kognitif siswa menjadi meningkat. Hal ini, dilihat dari nilai ketuntasan belajar siswa melalui hasil pretest dan postest.

Saran

Peneliti yang akan melakukan penelitian mengenai penerapan macromedia flash CS 6 terhadap hasil belajar siswa, disarankan agar lebih mengembangkan media pembejalaran macromedia flash Dengan mengembangkan media pembelajaran berbasis macromedia flash maka siswa dapat memahami materi yang diajarkan oleh guru.

\section{Daftar Pustaka}

Arikunto Suharsini. (2010). Prosedur Penelitian: Suatu Pendekatan Praktik. Jakarta: PT Rineka Cipta.

Cahyadi, D. (2014). Pengembangan Media Pembelajaran Berbasis Flash pada Mata Pelajaran IPA Terpadu Pokok Bahasan Wujud Zat Dan Perubahannya Kelas VII SMP Negeri 5 Satu Atap Bumijawa. Universitas Negeri Semarang. 
Citrasukmawati, A., Rahardjo, \& Tjandrakirana. (2012). Tampilan Macromedia Flash Di Smp. Jurnal Pendidikan Sains Pascasarjana Universitas Negeri Surabaya, 1(2), 94100.

Gustina, Nur Abu, S. H., \& Hamsyah, E. F. (2016). Pengaruh Penggunaan Media Pembelajaran Berbasis Macromedia Flash 8 Terhadap Motivasi dan Hasil Belajar Kognitif Siswa Kelas VII SMPN 18 Makassar Studi pada Materi Pokok Asam, Basa dan Garam Influence of MediaBased Learning Macromedia Flash 8 Motivation. Chemica, 17(2), 12-18.

Hartati, A, Triastuti ,W., \& Yuciana,W. (2013). Analisis Varian Dua Faktor Dalam Rancangan Pengamatan Berulang(Repeated Measures). Jurnal Gaussian,4(2),279-288.

Hilda, H., Yetri, \& Putra, F. G. (2018). Pengembangan Media Pembelajaran Berbasis Komputer. Jurnal Pemikiran Dan Penelitian Pendidikan, 16(2), 186203.

https://doi.org/10.24256/jpmipa.v1i2.95

Kominfo. (2014). Kemkominfo: Pengguna Internet di Indonesia Capai 82 Juta. http:/kominfo.go.id.

M, Affandi., Evi, C., \& Oktarina, P, Wardani. Model dan Metode Pembelajaran Di Sekolah. Semarang. Unissula Press.

Muhson, A. (2010). Pengembangan Media Pembelajaran Berbasis Teknologi Informasi. Jurnal Pendidikan Akuntansi Indonesia, 8(2). https://doi.org/10.21831/jpai.v8i2.949

Nasirudin, F., \& Mawartiningsih, L. (2017). Pengembangan Media Pembelajaran IPA Berbasis Macromedia Flash 8 Materi Pencemaran Lingkungan untuk Siswa SMP Kelas VII The Development of Science Learning Media Based on Macromedia Flash 8 Environmental Pollution Material for Junior High School Grade VII . 14, 509-516.

Nurchaili. (2010). Pengaruh Media Pembelajaran Berbasis Teknologi Informasi Dalam Proses Pembelajaran Kimia Terhadap Peningkatan Hasil Belajar Siswa. Jurnal Pendidikan Dan Kebudayaan, $\quad$ 16(6), 648. https://doi.org/10.24832/jpnk.v16i6.493

Nurdin, F., Sulastry, T., \& Hasri. (2018). Pengaruh Penggunaan Media Pembelajaran Berbasis Macromedia Flash 8 Pada Model Pembelajaran Kooperatif Melalui Pendekatan Saintifik Terhadap Motivasi Dan Hasil Belajar (Study Pada Materi Pokok Laju Reaksi). Chemistry Education Review (CER), 1(1), 29. https://doi.org/10.26858/cer.v0i1.5607

Nurharyani, D., Sardimi, \& Jumrodah. (2015). Pengaruh Media Animasi terhadap Hasil Belajar Konsep Sistem Peredaran Darah Manusia Siawa Kelas VIII MTs Raudhatul Jannah Palangkaraya. Jurnal EduSains, 3(2), 125-127.

Oktaviani, A, Mitha., \& Hari, B., N. (2014). Perbandingan Tingkat Konsistensi Normalitas Distribusi Metode KolmogrovSmirnov,Lilliefors,Shapiro-Wilk,dan Skewness-Kurtosis.Jurnal Biometrika dan Kependudukan.2(3).127-135.

Palupi, R., \& Anitah, S. (2014). Hubungan Antara Motivasi Belajar Dan Persepsi Siswa Terhadap Kinerja Guru Dalam Mengelola Kegiatan Belajar Dengan Hasil Belajar IPA Siswa Kelas VIII Di SMP N 1 Pacitan. Teknologi Pendidikan Dan Pembelajaran, 2(2), 157-170.

Santyasa, I. W. (2007). Landasan Konseptual Media Pembelajaran. In Workshop Media Pembelajaran bagi Guru-Guru SMAN Banjarangkan Klungkung. Banjarangkan Klungkung.

Sardiman, A. . (2011). Interaksi dan Motivasi Belajar Mengajar. Jakarta: Rajawali Pers.

Seh, A., Situmorang, R. P., \& Hastuti, S. P. (2018). Penerapan Model Inkuiri Terbimbing Berbantuan Marcromedia Flash Untuk Meningkatkan Motivasi Dan Hasil Belajar Siswa Kelas VIII Pada Materi Sistem Peredaran Darah Manusia Di SMP Kristen 4 Salatiga. Jurnal Wahana Didaktika, 16(2), 116-130. https://doi.org/10.31851/WAHANADIDA KTIKA.V16I2.2044

Setyono, T., Eka, L., Deswita, H., \& Belakang, A. L. (2017). Pengembangan Media Pembelajaran Matematika Dengan Menggunakan Macromedia Flash Pada Materi Bangun Ruang Kelas VIII Sekolah Menengah Pertama. Jurnal Fakultas 
Keguruan Dan Ilmu Pendidikan

Universitas Pasir Pengaraian, 2(1), 1-10.

Situmorang, R. P., \& Andayani, E. P. (2019).

Penggunaan Media Animasi Berbasis

Macromedia Flash untuk Meningkatkan

Hasil Belajar Siswa pada Konsep Materi

Sistem Peredaran Darah Manusia.

Assimilation: Indonesian Journal of

Biology Education, 2(1), 35-41.

Sugiyono. (2010). Metode Penelitian
Kuantitatif,Kualitatif dan $R \& D$. Bandung: Alfabeta. 